\title{
Effect of degree of hydrolysis on the functional properties of some oilseed proteins
}

\author{
By FS Taha* and MA Ibrahim
}

Fats and Oils Department, National Research Center, Cairo, Egypt.

\section{RESUMEN}

\section{Efecto del grado de hidrólisis sobre las propiedades} funcionales de proteínas de semillas oleaginosas.

Se ha efectuado la hidrólisis de harinas de haba de soja, sésamo y gérmen de arroz con las enzimas papaina y bromelaina bajo condiciones óptimas previamente determinadas. Se sacaron alicuotas de los hidrolizados a diferentes intervalos de tiempo para determinar la velocidad de degradación enzimática, así como el grado de hidrólisis de los hidrolizados. Con estos datos se eligieron doce hidrolizados con bajo y alto grado de hidrólisis, que fueron representativos de los tres sustratos y los dos enzimas ensayados. Se examinaron algunas propiedades funcionales de estos doce hidrolizados y luego se llevó a cabo un intento de correlacionarlas con el grado de hidrólisis. Las propiedades funcionales investigadas incluyeron: humectabilidad, dispersabilidad, fluidez, densidad volumétrica, índice de solubilidad del nitrogéno, capacidad de absorción de agua, capacidad de retención de aceite, gelación, termoestabilidad, capacidad emulsionante y estabilidad espumante. Los resultados mostraron una relación directa entre el aumento del grado de hidrólisis y la solubilidad del nitrogéno y la dispersabilidad. La humectabilidad, la fluidez y la capacidad emulsionante dieron mejores resultados con un grado de hidrólisis bajo.

PALABRAS-CLAVE: Bromelaina - Hidrólisis enzimática Papaina - Propiedades funcionales - Semilla oleaginosa.

\section{SUMMARY}

Effect of degree of hydrolysis on the functional properties of some oilseed proteins.

Hydrolyzing soybean, sesame, and ricebran meals with papain and bromelain enzymes under previously determined optimum conditions was accomplished. Aliquots were withdrawn from the bulk hydrolysates at different time intervals to determine the rate of enzymatic degradation, as well as the degree of hydrolysis of the hydrolysates at different time intervals. Twelve hydrolysates were then chosen with low and high degree of hydrolysis. They also represented hydrolysates from the three substrates hydrolysed with the two enzymes used. Some functional properties of the twelve hydrolysates were examined and then an attempt to correlate the functional properties with the degree of hydrolysis was done. The investigated functional properties included: wettability, dispersibility, flowability, bulk density, nitrogen solubility index,water absorption capacity, oil holding capacity, gelation, thermostability, emulsifying capacity and foam stability. Results showed a direct relation between increasing degree of hydrolysis and nitrogen solubility and dispersibility. Wettability, flowability and emulsifying capacity gave better results with low degree of hydrolysis.

KEY-WORDS: Bromelain - Enzymatic hydrolysis - Functional properties - Oilseeds - Papain.

\section{INTRODUCTION}

Proteolytic or enzymatic modification of food proteins is an ancient technology by which mankind has been able to improve palatability and storage stability of the available protein resources. The enzymatic hydrolysis or modification of proteins results in two types of hydrolysates. First, extensively hydrolyzed products with increased solubility, but these have few if any functional properties. They also possess a bitter taste. Recently, it became clear that the extent of proteolysis must be limited if some functional properties are to be mentained or enhanced. Second, partially hydrolyzed products. This group encompasses a wide range of products with varying degree of hydrolysis. The degree of hydrolysis (DH) is a measure of the extent of hydrolytic degradation of proteins and is the most widely used indicator among different protein hydrolysates $(1,2)$. Partially hydrolyzed proteins are prepared by stopping the hydrolysis process at a desired time. By this method a variety of products ranging in size from the original protein to small peptides or free amino acids can be obtained, based on the specificity of enzyme used and the relative rates of peptide bonds hydrolyzed. Another method of producing a controlled size-peptides is through the use of highly specific proteases so that only a few bonds are hydrolyzed and the further reaction stops (2).

Apart from their nutritional properties, the functional properties of protein or protein products must be taken into account as stated by Finch (3). Pour-El (4) had broadly defined functionality as any property of a food or food ingredient except its nutritional ones that affected its utilization. A listing of the key physico-chemical and related functional properties of protein hydrolysates include; solubility, viscosity, emulsification, foaming, thermostability, and flavor attributes are common to intact protein, but they differ from those of intact proteins by virtue of the $\mathrm{DH}(3,5)$. The functional properties of protein hydrolysates are also influenced by the specificity of enzyme used, the physical and chemical nature of intact protein, and hydrolysis conditions (5-8). The optimum conditions for the hydrolysis of soybean, 
sesame, and rice bran meal proteins using papain or bromelain were elucidated in previous paper (9).

The aim of the present study was to investigate the effect of the $\mathrm{DH}$ on the functional properties of partially hydrolysed proteins. To achieve this goal the same enzymes and substrates investigated in previous paper (9) were used The rate of enzymatic degradation was first determined followed by carrying partial hydrolysis by taking aliquots during the hydrolysis process, then determining their $\mathrm{DH}$. The functional properties of some chosen hydrolysates were then determined and the relation between the $\mathrm{DH}$ and functional properties were discussed.

\section{MATERIALS AND METHODS}

\subsection{Materials}

Soybean and sesame seed meal was prepared by dehulling, grinding and defatting with $\mathrm{n}$-hexane using a soxhlet apparatus. This extraction was carried out until the residual oil in the meal did not exceed $1 \%$. Rice bran was treated similarly with the omission of the dehulling step. The prepared meals were spread to dry at room temperature, and ground to pass an 80-mesh screen.

\section{Enzymes}

Papain: was from Difco Laboratories (MICHIGAN USA) and Bromelain: from Sigma (Misouri USA). All reagents were of analytical grade.

\subsection{Methods}

\subsubsection{Functional properties}

\subsubsection{Nitrogen Solubility Index as developed by Smith and Circle (10)}

In a $400 \mathrm{ml}$ beaker were mixed $5 \mathrm{~g}$ sample and $200 \mathrm{ml}$ water and the mixture was continuously stirred at $120 \mathrm{rpm}$ for 120 minutes at $30^{\circ} \mathrm{C}$. The mixture was transferred quantitatively in a $250 \mathrm{ml}$ volumetric flask, 2 drops of antifoaming agent added and diluted to mark with distilled water and mixed thoroughly. It was allowed to stand for a few minutes, then $40 \mathrm{ml}$ were decanted in a $50 \mathrm{ml}$ centrifuge tube and centrifuged for 10 minutes at $1500 \mathrm{rpm}$ and supernatant filtered through a funnel containing a plug of glass wool. The clear filtrate was collected in a $100 \mathrm{ml}$ beaker and aliquots were taken for nitrogen determination

$$
\% \text { Water soluble protein }=\frac{(\mathrm{S}-\mathrm{B}) \times \mathrm{N} \times 0.014 \times 100}{\text { Wt. of sample }}
$$

Where:

$\mathrm{S}=\mathrm{ml}$ of alkali back titration of sample

$\mathrm{B}=\mathrm{ml}$ of alkali back titration of blank

$\mathrm{N}=$ normality of alkali

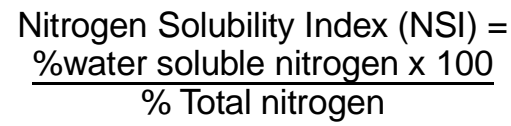

\subsubsection{Protein Dispersibility Index was determined according to Smith and Circle (10)}

$20 \mathrm{~g}$ sample were weighed. A $300 \mathrm{ml}$ volumetric flask was filled with distilled water at $25^{\circ} \mathrm{C}$. About 50 $\mathrm{ml}$ water were poured into a blender cup. The sample was transferred to the blender cup and stirred with a spatula to form a paste. The remaining water was added in increments with stirring to form a smooth slurry. Blend at $8,500 \mathrm{rpm}$ for 10 minutes. The slurry was poured into a $600 \mathrm{ml}$ beaker and after the slurry has separated decant or pipette a portion into $50 \mathrm{ml}$ centrifuge tube and centrifuge for 10 minutes at $2,700 \mathrm{rpm}$. Pipette $15 \mathrm{ml}$ of supernatant into a kjedahl flask and determine protein ( $15 \mathrm{ml}=1 \mathrm{~g}$ sample).

$\%$ Water dispersible protein $=$ $\frac{(\mathrm{S}-\mathrm{B}) \times \mathrm{N} \times 0.014 \times 100 \times 6.25}{\text { Wt. of sample }}$

Where:

$\mathrm{S}=\mathrm{ml}$ of alkali back titration of sample

$\mathrm{B}=\mathrm{ml}$ of alkali back titration of blank

$\mathrm{N}=$ normality of alkali

\section{Protein Dispersibility Index $(\mathrm{PDI})=$ $\%$ water dispersible protein $\%$ total protein}

\subsubsection{Water absorption capacity was} determined as described by Sosulski (11)

$5 \mathrm{~g}$ sample was weighed into a $50 \mathrm{ml}$ centrifuge tube and $40 \mathrm{ml}$ of distilled water were added from a burette the mixture was stirred with a stirring rod until homogenous. Centrifugation was carried out at 2000 rpm for 5 minutes. Decant the clear liquor back into the burette, which must contain water to at least the lowest graduation point. Determine the volume of the decanted liquor.

$\mathrm{Ml}$ of water absorbed $=40-\mathrm{ml}$ of decanted liquor

$\%$ Water absorption $=\frac{\mathrm{ml} \text { of water absorbed } \times 100}{W t \text { of sample }}$

\subsubsection{Wettability was determined as} described by Lucas Meyer (12)

Wettability means the ability of a powder to be wetted. It is expressed as the times in seconds a 
certain quantity of powder needs to penetrate into a calm water surface. A $400 \mathrm{ml}$ wide mouth beaker was filled with $150 \mathrm{ml}$ water and covered with a glass plate. A glass hopper was adjusted above the glass plate with the lower apperture $(30 \mathrm{~mm})$ on the plate.1g of the powder sample was poured into the hopper then the glass plate was drawn aside and powder was allowed to drop onto surface of the water. Time was stopped in seconds when powder was wetted.

\subsubsection{Flowability were carried out according to the method of Lucas Meyer (12)}

It signifies the ability of a powder to flow, it was measured in seconds as the time a certain powder required to leave a funnel $50^{\circ}$ wall inclination and $30 \mathrm{~mm}$ diameter lower opening.

\subsubsection{Bulk Density was also determined according to Lucas Meyer (12)}

In order to choose appropriate packaging units, it is advisable to determine the bulk density of any instantized product. $100 \mathrm{~g}$ powder was poured into a $250 \mathrm{ml}$ measuring cylinder quickly and the $\mathrm{cm}$-quantity was read immediately. Bulk density was stated in $\mathrm{g} / \mathrm{cm}$. The powder volume is usually indicated as $\mathrm{cm} / 100 \mathrm{~g}$ powder and can be converted into powder bulk density by the following formula:

$$
\text { Bulk density in } \mathrm{g} / \mathrm{cm}=\frac{100}{\mathrm{Cm} / 100 \mathrm{~g} \text { powder }}
$$

\subsubsection{Oil Holding Capacity measured as described by Childs and Forte (13)}

$0.1 \mathrm{~g}$ of sample was added to a previously weighed $15 \mathrm{ml}$ glass centrifuge tube and then $5 \mathrm{ml}$ cottonseed oil was added. The tube and contents were agitated with a Vortex mixer for $1 \mathrm{~min}$ and then centrifuged for 15 minutes at $1000 \mathrm{rpm}$. The supernatant oil was decanted and the weight if oil bound per gram sample was calculated.

\subsubsection{Gelation was carried out according to Circle et al. (14)}

A series of solutions at 2, 3, 4, 5, 6, 7, 8, 10, 12 and $14 \%$ concentration for the protein sample was added to glass stoppered tubes. The tubes were heated to $75-80^{\circ} \mathrm{C}$ for 30 minutes in a water bath, then were placed in test-tube racks in ice and left in a cold room at $4^{\circ} \mathrm{C}$ for 60 minutes. At the end of the time interval the racks were removed from the ice and each tube was taken to test the stability of gel. The tubes containing stable gels were inverted and left in the rack for 30 minutes. The results were reported in terms of the lowest concentration of protein that remained stable after 30 minutes at room temperature.

\subsubsection{Emulsifying Capacity was determined according to Swift et al. (15)}

$100 \mathrm{mg}$ of protein product were mixed with $30 \mathrm{ml}$ of $1 \mathrm{~N}-\mathrm{NaCl}$ and heated at $80^{\circ} \mathrm{C}$ for 5 minutes, then blended in an Omni Mixer at 1000 rpm for 2 minutes after the addition of $20 \mathrm{ml}$ of corn oil. Cutting and mixing at $13000 \mathrm{rpm}$ for 30 seconds. Further addition of oil was continued at a rate of $0.8 \mathrm{ml} / \mathrm{second} \mathrm{until}$ the emulsion broke and the phase transition occurred. Emulsifying capacity was reported as $\mathrm{ml}$ oil added to $100 \mathrm{ml}$ protein product.

\subsubsection{Thermostability was measured by the method of Kramer and Kwee (16)}

Suspensions of protein samples and enzyme modified protein samples $(2 \%, \mathrm{pH} 6.8)$ were agitated on a magnetic stirrer for 15 minutes and 2 aliquots (10 $\mathrm{ml}$ each) were placed in screw capped test tubes and heated in a boiling water bath for 20 minutes. After rapid cooling to $22^{\circ} \mathrm{C}$ and centrifugation at 2000 rpm for 20 minutes, the protein content of the supernatant was assayed. Thermal aggregation of enzyme modified hydrolysate was represented in the difference in protein content of supernatant caused by heating.

\subsubsection{Foam Stability was determined according to AOAC official methods of analysis (17)}

$1 \%$ protein dispersion was prepared and $25 \mathrm{ml}$ of this dispersion were taken and placed in a quick fit measuring cylinder and closed with stopper the solution was shaken until it turned into a foam, the time was recorded. Another $25 \mathrm{ml}$ of the protein dispersion were shaken for a period of time less than which turned it all into foam. The time of shaking and volume after shaking were recorded.

$$
\text { Foam Stability }=t / 2.303 \times \log \frac{b+c}{c}
$$

\footnotetext{
Where:

$\mathrm{t}=$ time in seconds

$\mathrm{b}=$ volume of solution settling from foam during time $\mathrm{t}$

$\mathrm{C}=$ volume of solution remaining in foam during time $\mathrm{t}$
}
2.2.1.12. Nitrogen Solubility was determined according to Lyman et al. (18)

$1 \mathrm{~g}$ sample was weighed in $300 \mathrm{ml}$ Erlenmeyer flask to which $100 \mathrm{ml}$ of $0.02 \mathrm{~N}-\mathrm{NaOH}$ solution were 
added and the flask was shaken on a mechanical shaker in an incubator at $30^{\circ} \mathrm{C}$ for 1 hour. The material was then centrifuged at $5000 \mathrm{rpm}$ for 10 minutes. $1 \mathrm{ml}$ aliquots were taken from supernatant for nitrogen determination. Nitrogen solubility was expressed as percent total nitrogen which was soluble in $0.02 \mathrm{~N}-\mathrm{NaOH}$

$$
\begin{gathered}
\% \text { Nitrogen Solubility }= \\
\frac{\% \text { nitrogen soluble in } 0.02 \mathrm{~N} \mathrm{NaOH}}{\% \text { total nitrogen }} \times 100
\end{gathered}
$$

\subsection{Experimental}

\subsubsection{Enzymatic hydrolysis of protein}

In a typical experiment a glass beaker containing a distilled water dispersion of the meal (calculated to contain 5\% meal protein) was placed in a thermostatic water bath. The dispersion was continuously stirred with an electric stirrer, the $\mathrm{pH}$ and temperature were adjusted as previously determined by Taha et al. (9). The enzyme was added and stirring continued for the required time after which the reaction was stopped with $0.05 \mathrm{M}$ trichloro acetic acid. The $\mathrm{pH}$ and temperature for each enzyme on each substrate as determined previously (9) were: when using papain on soybean meal $\left(\mathrm{E} / \mathrm{S} 0.06, \mathrm{pH} 7.2\right.$, temp. $\left.50^{\circ} \mathrm{C}\right)$ on sesame meal (E/S 0.29, $\mathrm{pH} 7.0$, temp $50^{\circ} \mathrm{C}$ ) on rice bran meal $(\mathrm{E} / \mathrm{S}$ $0.10, \mathrm{pH} 7.0$, temp. $50^{\circ} \mathrm{C}$ ) and when using bromelain on soybean meal ( $\mathrm{E} / \mathrm{S} 0.07, \mathrm{pH} 6.0$, temp. $\left.45^{\circ} \mathrm{C}\right)$ on sesame meal $\left(\mathrm{E} / \mathrm{S} 0.058, \mathrm{pH} 6.0\right.$, temp. $\left.45^{\circ} \mathrm{C}\right)$ on rice bran meal (E/S 0.21, pH 6.0, temp $\left.45^{\circ} \mathrm{C}\right)$.

\subsubsection{The Rate of Enzyme Degradation}

This was determined by taking $10 \mathrm{ml}$ aliquots of hydrolysates at $5,10,15,20,25,30,60,120$ minutes, and carrying formol titration on the aliquots. The amount of $0.1 \mathrm{~N} \mathrm{NaOH}$ consumed by the formol titration (19) was plotted against the time of the reaction. $\mathrm{MI} \mathrm{NaOH}$ represent the amount of $-\mathrm{COOH}$ group present in the $10 \mathrm{ml}$ hydrolysate. The acidity as shown by the titration is an approximate measure of the amino nitrogen present.

\subsubsection{Partial hydrolysis of meal protein}

The experiment was carried as in experiments 1 and 2, then removing $25 \mathrm{ml}$ aliquots at 5 minutes intervals and determining their degree of hydrolysis using the Formol titration method .The hydrolysates with different $\mathrm{DH}$ were spray dried and the powder kept in a dessicator for analysis of the functional properties.

\subsubsection{Degree of Hydrolysis $(D H)$}

From experiment 2.3.3.

$$
\% \mathrm{DH}=\frac{\left(\mathrm{B}_{2}-\mathrm{B}_{1}\right) \times 14}{\mathrm{SW} X \mathrm{TN}}=\frac{\mathrm{AN} \times 100}{\mathrm{TN}}
$$

\section{$\mathrm{B}_{1}=\mathrm{mL} 0.1 \mathrm{~N}-\mathrm{NaOH}$ consumed by sample at certain time \\ $\mathrm{B}_{2}=\mathrm{ml} 0.1 \mathrm{~N}-\mathrm{NaOH}$ consumed by blank \\ $14=$ atomic weight of nitrogen \\ $\mathrm{SW}=$ amino nitrogen assayed by formol titration $\mathrm{TN}=$ total nitrogen assayed by micro kjeldahl method.}

\section{RESULTS AND DISCUSSION}

\subsection{Rate of Enzymatic Degradation}

Figures 1 and 2 are diagrammatic representations of the rate of enzymatic degradation of soybean, sesame, and rice bran meal proteins with papain and bromelain enzymes, respectively, under the optimum conditions of $\mathrm{E} / \mathrm{S}, \mathrm{pH}$, and temperature previously determined (9), and at different time intervals.

Figure 1 shows that when soybean meal protein was hydrolyzed with papain the rate of degradation kept increasing up to 20 minutes after which it became constant. While on hydrolysis of sesame and rice bran meal protein with papain the rate of degradation kept increasing until one hour after which it remained unchanged. It is clear from Figure 2 that when using the enzyme bromelain for the three oilseed meal protein substrates; the rate of enzymatic degradation kept increasing until 30 minutes after which a plateau was reached.

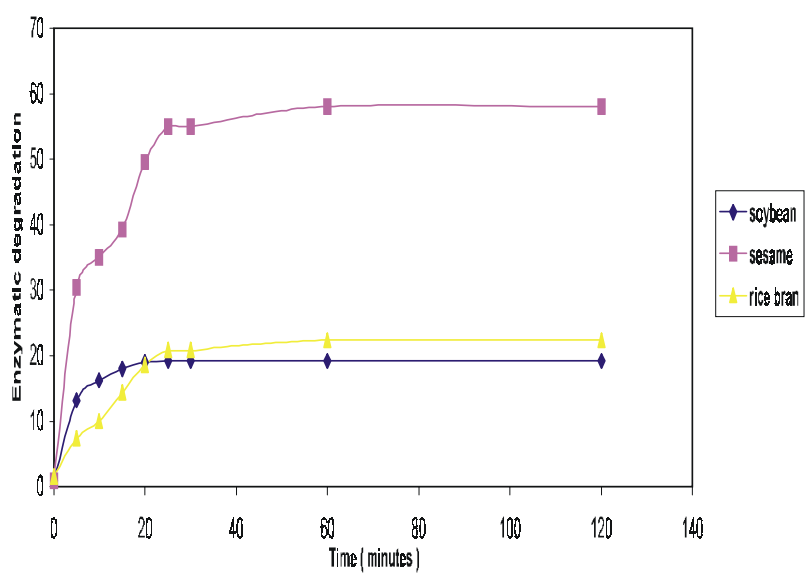

Figure 1

Rate of enzymatic degradation of the three substrates hydrolyzed with papain. 


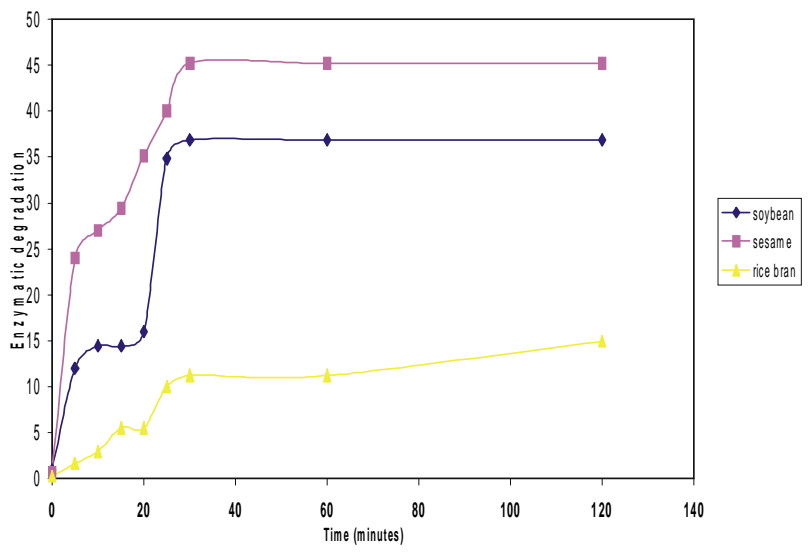

Figure 2

Rate of enzymatic degradation of three substrates hydrolyzed with bromelain

\subsection{Degree of Hydrolysis}

Degree of hydrolysis is defined as the percentage of peptide bonds cleaved during the reaction.

Tables III and IV give the DH for the partially hydrolyzed soybean, sesame, and rice bran meal proteins when proteolytic enzymes papain and bromelain were used, respectively. The values of $\mathrm{DH}$ in tables I and II may be useful in preparing hydrolysates with certain functional properties, since the $\mathrm{DH}$ is the principle determinant of protein hydrolysate properties $(1,2)$. From Tables I and II, twelve hydrolysates were chosen for further study. These hydrolysates were those hydrolysates of soybean, sesame, and rice bran with the least $\mathrm{DH}$ using both papain and bromelain, that corresponded to 5 minutes of hydrolysis. This choice was based on the fact that at the beginning of the hydrolysis process, hydrolysates with low $\mathrm{DH}$ will exhibit low bitterness (20). The other chosen hydrolysates were those resulting after 30 minutes hydrolysis, where the $\mathrm{DH}$ in most cases did not show much increase after 30 minutes, except in the case of rice bran hydrolysed with bromelain where there was a clear increase in $\mathrm{DH}$ between 30 and 120 minutes hydrolysis. For simplification, the hydrolysates of the three substrates chosen after 30 minutes of hydrolysis were:

\begin{tabular}{lllcc}
\hline \multicolumn{1}{c}{ Symbol } & Substrate & Enzyme & Time( min.) & \%DH \\
\hline SbH1 & Soybean & Papain & 5 & 9.1 \\
SbH2 & Soybean & Papain & 30 & 13.8 \\
SbH3 & Soybean & Bromelain & 5 & 7.3 \\
SbH4 & Soybean & Bromelain & 30 & 26.9 \\
SbH & Soybean & - & - & control \\
SH1 & Sesame & Papain & 5 & 8.7 \\
SH2 & Sesame & Papain & 30 & 45.7 \\
SH3 & Sesame & Bromelain & 5 & 15.3 \\
SH4 & Sesame & Bromelain & 30 & 34.6 \\
SH & Sesame & - & - & control
\end{tabular}

\begin{tabular}{lclcc}
\hline Symbol & Substrate & Enzyme & Time( min.) & \%DH \\
\hline RH1 & Rice bran & Papain & 5 & 8.8 \\
RH2 & Rice bran & Papain & 30 & 57.9 \\
RH3 & Rice bran & Bromelain & 5 & 2.7 \\
RH4 & Rice bran & Bromelain & 30 & 50.7 \\
RH & Rice bran & - & - & control \\
\hline
\end{tabular}

Table I

Degree of hydrolysis (\%DH) during partial hydrolysis of the three substrates when using papain enzyme

\begin{tabular}{|c|c|c|c|c|c|c|c|c|}
\hline \multirow{2}{*}{ Substrate } & \multicolumn{5}{|c|}{ Time (minutes) } & \multirow[b]{2}{*}{30} & \multirow[b]{2}{*}{60} & \multirow[b]{2}{*}{120} \\
\hline & 5 & 10 & 15 & 20 & 25 & & & \\
\hline Soybean & 9,5 & 11,5 & 12,9 & 13 & 13,3 & 13,3 & 13,3 & 13,3 \\
\hline Sesame & 8,7 & 16,4 & 18,4 & 23,2 & 25,8 & 25,8 & 27,2 & 27,2 \\
\hline Rice bran & 8,8 & 12 & 16,7 & 22,2 & 24,8 & 24,8 & 26,7 & 26,7 \\
\hline
\end{tabular}

Table II

Degree of hydrolysis (\%DH) during partial hydrolysis of the three substrates when using bromelain enzyme

\begin{tabular}{lccccccccc}
\hline & \multicolumn{7}{c}{ Time ( minutes) } \\
Substrates & 5 & 10 & 15 & 20 & 25 & 30 & 60 & 120 \\
\hline Soybean & 7,3 & 9,1 & 9,1 & 10,4 & 25,3 & 26,9 & 26,9 & 26,9 \\
Sesame & 15,3 & 17,3 & 18,8 & 22,5 & 26,2 & 29,1 & 29,1 & 29,1 \\
Rice bran & 2,7 & 5,9 & 14,7 & 14,7 & 26,7 & 29,3 & 29,3 & 39,7 \\
\hline & & & & & & & &
\end{tabular}

\subsection{Functional Properties and their relation to the degree of hydrolysis}

Certain functional properties of the protein hydrolysates play a more dominant role than others and dictate the choice of hydrolysates for a specific end use. The range of desirable and attractive functional properties that should be looked for is almost as broad as the range of foods themselves.

Table III gives the determined values for the functional properties of the chosen hydrolysates under investigation. 
Table III

Functional properties of chosen hydrolysates

\begin{tabular}{|c|c|c|c|c|c|c|c|c|c|c|c|c|c|c|}
\hline Chosen hydrolysates & $\mathrm{SbH} 1$ & $\mathrm{SbH} 2$ & $\mathrm{SbH} 3$ & $\mathrm{SbH} 4$ & $\mathrm{SbH}$ & SH1 & SH2 & $\mathrm{SH} 3$ & $\mathrm{SH} 4$ & SH & RH1 & RH2 & RH3 & RH4 \\
\hline \multicolumn{11}{|l|}{ Functional properties } & 8,8 & 24,8 & 2,7 & 29,3 \\
\hline Wettability(sec) & 4 & 6 & 10 & 13 & 16 & 8 & 5 & 7 & 4 & 14 & 25 & 50 & 27 & 30 \\
\hline Protein dispersibility index(PDI) & 9,05 & 12,31 & 18,82 & 22,6 & 16,25 & 3,72 & 6,29 & 13,24 & 11,79 & 8,73 & 6,45 & 8,33 & 7,12 & 8,66 \\
\hline Flowability(sec) & 25 & 10 & 10 & 10 & 30 & 20 & 10 & 10 & 10 & 30 & 150 & 160 & 20 & 10 \\
\hline Bulk density $(\mathrm{g} / \mathrm{cm})$ & 0,723 & 0,714 & 0,676 & 0,685 & 0,625 & 0,74 & 0,74 & 0,78 & 0,75 & 0,25 & 0,42 & 0,39 & 0,3 & 0,36 \\
\hline Nitrogen solubility index(NSI) & 25,85 & 31,4 & 18,66 & 30,54 & 15,48 & 37,08 & 50,01 & 20 & 52,3 & 28,3 & 41,58 & 60,43 & 46,34 & 53,13 \\
\hline Nitrogen solubility \% & 100 & 95,91 & 89,8 & 93,9 & 88,31 & 98,2 & 99,9 & 99,5 & 100 & 89,9 & 58,29 & 44,8 & 46,34 & 53,13 \\
\hline Water absorption capacity (WAC\%) & 320 & 320 & 300 & 320 & 300 & 340 & 340 & 300 & 180 & 320 & 360 & 320 & 400 & 380 \\
\hline Oil holding capacity (OHC\%) & 3,58 & 1,49 & 3,72 & 1,295 & 1,875 & 1,66 & 2,06 & 1,18 & 1,57 & 2,36 & 2,36 & 1,88 & 1,41 & 2,38 \\
\hline Gelation\% & 2 & 2 & 2 & 2 & 3 & 2 & 2 & 2 & 2 & 3 & 2 & 2 & 2 & 2 \\
\hline Emulsifying capacity(ml oil/100g sample) & 21,6 & 21,2 & 21,6 & 20,8 & 20,8 & 21,8 & 20,8 & 20,8 & 21,8 & 20,8 & 21,6 & 20,8 & 21,2 & 21,6 \\
\hline Term ostability(\%) & 17,9 & 25 & 33,3 & 93,7 & 40 & 62,5 & 70 & 40 & 38,9 & 62,2 & 16,7 & 25 & 44,4 & 25 \\
\hline \multicolumn{15}{|l|}{ Foam stability(setting time) } \\
\hline $30 \mathrm{sec}$ & 14,1 & 9,3 & 7,7 & 9,3 & 32,5 & 9,3 & 18,6 & 21,7 & 10,8 & 41,9 & 7,6 & 11,8 & 11,8 & 14,1 \\
\hline $60 \mathrm{sec}$ & 28,4 & 23,7 & 18,5 & 23,7 & 130,5 & 26,1 & 28,4 & 28,4 & 23,7 & 87 & 15,4 & 28,1 & 23,7 & 32,6 \\
\hline $90 \mathrm{sec}$ & 55,9 & 35,5 & 35,5 & 35,6 & 195,5 & 35,5 & 65,2 & 65,2 & 35,6 & 130,3 & 27,9 & 39,1 & 42,5 & 48,9 \\
\hline $120 \mathrm{sec}$ & 65,13 & 47,4 & 47,4 & 47,4 & 260 & 47,4 & 47,4 & 74,4 & 47,4 & 280,5 & 43,4 & 56,6 & 56,6 & 74,4 \\
\hline \multirow{2}{*}{\multicolumn{4}{|c|}{$\mathrm{SbH} 1$ : soybean meal hydrolyzed with papain for $5 \mathrm{~min}$. }} & \multicolumn{7}{|c|}{ SH1; sesame meal hydrolyzed with papain for $5 \mathrm{~min}$} & \multirow{3}{*}{\multicolumn{4}{|c|}{$\begin{array}{l}\text { RH1 : rice bran meal hydrolyzed with papain } 5 \mathrm{~min} \\
\text { RH2 : rice bran meal hydrolyzed with papain } 30 \mathrm{~min}\end{array}$}} \\
\hline & & & & SH2 : sesa & meal hyd & & n for 30 & & & & & & & \\
\hline \multirow{2}{*}{\multicolumn{4}{|c|}{$\mathrm{SbH} 3$ : soybean meal hydrolyzed with bromelain for $5 \mathrm{~min}$}} & \multicolumn{7}{|c|}{ SH 3 : sesame meal hydrolyzed with bromelain for $5 \mathrm{~min}$} & & & & \\
\hline \multirow{2}{*}{\multicolumn{4}{|c|}{$\begin{array}{l}\text { SbH4 : soybean meal hydrolyzed with bromelain for } 30 \mathrm{~min} \\
\text { SbH : non hydrolyzed soybean meal }\end{array}$}} & \multirow{2}{*}{\multicolumn{7}{|c|}{$\begin{array}{l}\text { SH4 : sesame meal hydrolyzed with bromelain for } 30 \mathrm{~min} \\
\text { SH : non hydrolyzed sesame meal }\end{array}$}} & & & & \\
\hline & & & & & & & & & & & \multicolumn{4}{|c|}{ RH : non hydrolyzed rice bran meal } \\
\hline
\end{tabular}

Wettability: The data in table III reveals that enzymatic hydrolysis at both high and low $\mathrm{DH}$ generally results in improvement of the wettability property when using both enzymes. In general low $\mathrm{DH}$ gave better results of wettability than high $\mathrm{DH}$ when using the same enzyme and substrate. Papain lowered the wettability time of soybean and rice bran hydrolysates compared to bromelain. Hydrolyzing soybean meal with papain for 5 minutes resulted in $75 \%$ improvement in wettability over the non hydrolyzed soybean meal. Hydrolysing sesame meal with bromelain for 30 minutes improved the wettability of hydrolysate $97 \%$ over the non hydrolyzed sesame meal. Best improvement in wettability for rice bran was achieved with papain at low $\mathrm{DH}$. Thus enzymatic hydrolysis is recommended to improve wettability of soybean and sesame meal protein, but not that of rice bran meal protein.

Protein Dispersibility Index (PDI): Dispersibility of the hydrolysed products of soybean,sesame, and rice bran meals using papain for 5 minutes were improved by $44 \%, 57.4 \%$ and $82.3 \%$, respectively, over their nonhydrolysed protein (table III). Hydrolysing soybean and sesame meals with bromelain results in deterioration in their dispersibility. In general, the lower the $\mathrm{DH}$ the better is the dispersibility.

Flowability: Hydrolyzing soybean and sesame meals with papain and bromelain for 5 minutes and 30 minutes results in improvement of the flowability of the hydrolysates over the nonhydrolysed meals. Rice bran meal hydrolysed with papain results in a great increase in the flowability property of the hydrolysate. On the other hand hydrolysing it with bromelain 30 minutes results in improvement of flowability. Both low and high $\mathrm{DH}$ are recommended to improve flowing properties of soybean and sesame protein hydrolysates, yet high $\mathrm{DH}$ resulted in more improvement in flowability.

Bulk Density: Is an important factor since it helps in choosing the appropriate packaging units, it is stated as $\mathrm{g} / \mathrm{cm}^{3}$. Soybean and sesame meals treated with both papain and bromelain show an increase in bulk density over their corresponding untreated meals, which means larger packing units. On the other hand rice bran hydrolysates show a decrease in the bulk density over nonhydrolysed meal, meaning smaller packing units. No relation could be drawn between $\mathrm{DH}$ and bulk density.

Nitrogen Solubility Index (NSI):Is a very important measure of the functionality of the proteins in different food systems, especially in fortifying nutritious beverages. There is a great increase in the NSI of all hydrolysates over the non hydrolysed meals from which they were prepared (TABLE III). This result is confirmed by the nitrogen solubility carried according to Lyman (18) technique in table III. A direct relation between $\mathrm{DH}$ and nitrogen solubility could be drawn, increasing the $\mathrm{DH}$ results in an increase in nitrogen solubility.

Increased solubility of diverse proteins through enzymatic hydrolysis has been extensively reported by $(4,21-26)$. These studies concluded that even partial or limited hydrolysis produced substantially increased solubility of the resulting hydrolysates, particularly at the isoelectric point of the parent protein. The enhanced solubility of the hydrolysates is due to their smaller molecular size $(24,27)$, and the newly exposed ionizable amino and carboxyl groups that increase the hydrolysate's hydrophobicity (28) .

Results of wettability, dispersibility, flowability, and nitrogen solubility, predicted the good performance 
of the chosen hydrolysates in instant food products and beverages.

Water Absorption Capacity (WAC): Is the ability of a product to absorb water or swell. This property is important in the manufacture of bakery products, pastas, doughnuts and others. The hydrolysates of soybean with both enzymes show a slight improvement in their WAC over soybean meal. Also hydrolysates of sesame using papain show increase in WAC, but sesame hydrolyzed with bromelain and all rice bran hydrolysates show a decrease in WAC over the original meals prepared therefrom. This suggests that only soybean hydrolysates and sesame hydrolyzed with papain can be used for bakery and pasta fortification. No relation could be drawn between DH and WAC. Generally enzymatic hydrolysis is not recommended to improve WAC.

Oil Holding Capacity $(\mathrm{OHC})$ : Is the ability of a protein to bind with oil. Is an important criterion in the meat industry (sausages, hamburgers etc.) and also in the doughnut industry. Table III shows that hydrolyzing soybean meal with papain and bromelain for 5 minutes increases the $\mathrm{OHC}$ from $1.9 \%$ for nonhydrolysed soy meal to $3.6 \%$ and $3.7 \%$ for soybean hydrolysed with papain and bromelain, respectively, while hydrolysing soybean with both enzymes for 30 minutes decreases the OHC. All sesame hydrolysates showed decrease in their $\mathrm{OHC}$ over their nonhydrolysed meal. Rice bran hydrolysed with papain for 5 minutes showed increase in the $\mathrm{OHC}$ over rice bran meal. No relation could be drawn between $\mathrm{DH}$ and $\mathrm{OHC}$. The results indicate that only soybean hydrolysed with both enzymes for 5 minutes and rice bran hydrolysed with papain for 5 minutes can perform well in meat systems.

Choi and Rhee (29) studied enzymic hydrolysis of conventionally produced soy protein isolate, and of $7 S$ and $11 S$ rich fractions with pronase and alcalase. They found that changes in oil absorption capacity after modification varied with protein fraction and enzyme. Ponnamplan et al. (30) working with oat flour found that proteolysis reduced emulsifying stability, fat binding capacity, and heat coagulability when compared to soy flour.

Gelation: Is important in comminuted meat products as a protein's emulsifying capacity. It is reported as the lowest concentration of protein that remained as a stable gel after 30 minutes at room temperature. Table III indicates that all hydrolysates gelled at $2 \%$ protein concentration, while the three non hydrolyzed meals gelled at $3 \%$ protein concentration. No relation could be drawn between $\mathrm{DH}$ and gelation, but generally enzymatic hydrolysis is not recommended to improve gelation.

Adler-Nissen and Olsen (21) and Mahmoud (31) observed no gel formation for soy protein hydrolysates and explained the inability of hydrolysates to form heat induced gels by the reduced hydrophobicity of protein hydrolysates. Mahmoud (31) also suggested that presumably the increased charge repulsion between the peptides would lead to their loss of gelation ability.

Emulsifying Capacity (EC): Emulsifying and film forming ability of plant proteins is essential for those proteins to perform well in meat systems. Also a protein's ability to form emulsions is critical to their application in mayonnaise, salad dressing, milks, frozen deserts. Results in Table III show an improvement in the emulsifying capacities of all hydrolysates when hydrolysed for 5 minutes with both papain and bromelain. I t can be concluded that the lower the $\mathrm{DH}$ the better is the emulsifying property of the hydrolysates.

It is generally accepted that the emulsifying property of hydrolyzed proteins was improved by carefully controlling the extent of hydrolysis $(21,31)$. Philips and Beuchat (28) explained the observed improvement in the emulsifying property upon very limited hydrolysis that it could be presumably attributed to exposure of the hydrophobic protein interior which enhances adsorption at the interface, forming a cohesive interfacial film, with the hydrophobic residues interacting with oil and hydrophylic residues with water. It was also reported that as the extent of hydrolysis increased the emulsifying capacity decreased (2). Arias and Felacio (22) on hydrolysing sesame meal with bacterial protease found decrease in the emulsifying capacity as hydrolysis proceeded. Bernardi et al. (25) working with soy protein concentrate found emulsifying capacity to be unchanged when hydrolysing with fungal or bacterial protease, but emulsion stability decreased. Cha and Yoon (32) studied enzymatic modification of soy protein isolate using papain and actinidin. They observed that emulsifying capacity and emulsifying stability showed a marked decrease in the $\mathrm{pH}$ range 3-8.

Thermostability: Is the ability of a protein hydrolysate to remain soluble without aggregation leading to precipitation under elevated processing and sterilization temperature. Results in Table III show that hydrolysates of soybean show a decrease in their thermostability compared to the soybean meal. Sesame hydrolyzed with papain for 30 minutes show an increase in thermostability over sesame meal, rice bran meal show a $20 \%$ thermostability, which is increased to $25 \%$ on hydrolysis with both papain and bromelain for 5 minutes, and to $44 \%$ on hydrolysis with bromelain for 30 minutes. No relation could be drawn between $\mathrm{DH}$ and thermostability.

Mahmoud (31) studied the thermostability in extensively hydrolyzed soy protein and casein in hypoallergenic infant formulae and found that the hydrolysates remained soluble during UHT treatment $\left(150^{\circ} \mathrm{C}\right)$ and subsequent retort sterilization $\left(132^{\circ} \mathrm{C}\right)$. 
Foam Stability: Is the capacity to form stiff, stable foam and is an important requirement of proteins to be incorporated into a gel cakes,whipped toppings, deserts, and soufflé-like products. Table III show that all treatments resulted in a decrease in the foam stability of the hydrolysates when compared to the meals prepared therefrom. No relation was found between $\mathrm{DH}$ and foam stability. Thus these hydrolysates cannot be incorporated into any of the above food items.

Hermanson et al.(33), Kang (34) both reported enzymatic hydrolysis to decrease foam stability. While Bernardi et al. (25) and Cha and Yoon (32) reported that enzymic modification of soybean protein products improved the foaming property.

Bitterness: the staff of our department tasted the hydrolysates, they did not detect any bitterness.

It can be concluded from the above results of the previous work that no definite correlation could be drawn between the degree of hydrolysis and most of the functional properties investigated.

A direct correlation could be made in the following cases:

- Nitrogen solubility of hydrolysates is directly proportional to the degree of hydrolysis, the higher the degree of hydrolysis the more the protein solubilized.

- Dispersibility of hydrolysate is also directly proportional to $\mathrm{DH}$, although not necessarily improved over the nonhydrolysed meals.

- Wettability, flowability, and emulsifying capacity are improved at low degree of hydrolysis then decrease with increasing degree of hydrolysis.

\section{REFERENCES}

1. Mahmoud,M.I., Malone, W.T. and Cordle, C.T. (1992). Enzymatic hydrolysis of casein: Effect of degree of hydrolysis on antigenicity and physical properties.J. Food Sci 57, 1223-1229

2. Adler-Nissen,J.Editor (1986). Enzymatic Hydrolysis of Food Proteins. Chapter 4, p 57 and 81, Elsevier Applied Science Publishers .

3. Finch,R.(1970). Fish protein for human foods. CRC Reviews in Food Technol 1 (4), 519.

4. Pour-El, A. (1981). Protein functionality: classification, definition and methodology. Chapter 1 in Protein Functionality in Foods. Ed. J.P Cherry pp1-9, American Chemical Society Symposium Series 147, Washington DC.

5. Kester, J.J. and Richardson, T.(1984). Modification of whey proteins to improve functionality. J. Dairy Sci 67 , 2757-2774.

6. Vodjdani, F. and Whitaker, J.R .(1989). Chemical and enzymatic modification of proteins for improved functionality. Chapter 9 in Protein Functionality in Food Systems. Editors, Hettiarachchy N.S. and Ziegler C.R., Marcel and Decker Inc., New York.

7. Rhee, K.C. (1989). Functionality of soy protein. Chapter 10 in Protein Functionality in Food Systems. Editors, Hettiarchchy N.S and Ziegler CR, Marcel and Decker Inc., New York.
8. Gauthier, S.F., Paqiun, P., Pouliot, Y. and Thurgeon, S. (1993). Surface activity and related functional properties of peptides obtained from whey proteins. $J$. Dairy Sci 76, 321-328

9. Taha, F.S., Ibrahim, M.A and El-Zanaty, E.A. (2001). Optimum conditions for enzymatic degradation of some oilseed proteins. Grasas y Aceites, 53,

10. Smith, A.K. and Circle, S.J., Editors (1997). Nitrogen Solubility Index and Protein Dispersibility Index. In Soybean: Chemistry and Technology. Volume I, Proteins, Appendix pp 451-454 AVI Publishing Co.

11. Sosulski, F.W. (1962). The centrifuge method for determination of flour absorption in hard red spring wheat. Cereal Chem. 39, 344.

12. Lucas Meyer GmbH \& Co. Publication Instantizing with Metarin pp 13-14 (1982).

13. Childs, E.A. and Forte, J.F. (1976). Enzymatic and ultrasonic techniques for solubilization of protein from heat-treated cottonseed products. J. Food Sci 41, 652-655.

14. Circle,S.J., Meyer,E.W. and Whitney, R.W.(1964). Rheology of soy protein dispersions :Effect of heat and other factors on gelation. Cereal Chem 41, 157 .

15. Swift, C.E., Lochert, C. and Fryar, A.J. (1961). Comminuted meat emulsions: The capacity of meat for emulsifying fat. Food Technol. 15, 468 .

16. Kramer, A. 7. and Kwee, W.H. (1977). Functional and nutritional properties of tomato protein concentrate. $J$. Food Sci. 42, 207.

17. A.O.A.C. "Official Methods of Analysis" $10^{\text {th }}$ edition, Association of Official Agricultural Chemists, Washington DC, 1985.

18. Lyman ,C.M., Chang, W.Y. and Couch, J.R. (1953). Evaluation of protein quality in cottonseed meals by chick growth and chemical index method. J. Nutrition 49, 679-690

19. Taylor, W.H.(1957). Formol Titration : An evaluation of its various modifications. Analyst 82, 488- 498.

20. Matoba, T. and Hata, T.(1972). Relationship between bitterness of peptides and their chemical structure. Agric. Biol. Chem. 36, 1423-1431.

21. Adler-Nissen, J. and Olsen,H.S. (1979). The influence of peptide chain length on taste and functional properties of enzymatically modified soy protein. Chapter 7, pp 120-146 in Functionality and Protein Structure. Editor Pour-El A, American Chemical Society Symposium Series 92, Washington, DC.

22. Arias, F.G. and Felacio,A.C.H. (1988). Exploratory study of the enzymatic hydrolysis of sesame seed protein. Technologia 26 (164), 21-36.

23. Chobert , J.M.,Bertrand-Harb, C., Dalgalarrando, M. and Nicolas, M.G. (1989). Solubility and emulsifying properties of beta-casein modified enzymatically by trypsin. J. Food Biochem. 13, 335-352.

24. Chobert,J.M., Sitohy,M.Z. and Whitaker,J. (1988). Solubility and emulsifying properties of caseins modified enzymatically by Staphylococcus aureus V8 protease. J.Agric. Food Chem. 3, 220-224.

25. Bernardi,Don, L.S., Pilosof, A.M.R. and Bartholomi, G.B.(1991). Enzymatic modification of soy protein concentrate by fungal and bacterial proteases. J. Amer Oil Chemist's Soc 68, 102-105.

26. Thurgeon,, S.L., Gauthier, S.F., Molle, D. and Leonil, J. (1992). Interfacial properties of tryptic peptides of B-lactoglobulin. J. Agric. Food Chem. 40, 669-675.

27. Arzu, A., Mayorga, H., Gonzalez, J. and Polz, C. (1972). Enzymatic hydrolysis of cottonseed protein.J. Agric Food Chem 20, 805-809. 
28. Phillips, R.D. and Beuchat, L.R.(1981). Enzyme modification of proteins. Chapter 13, pp 275-298 in Protein Functionality in Foods. Editor Cherry J.P. American Chemical Society Symposium Series 147, Washington DC.

29. Choi, Y.R. and Rhee, K.C.(1984). Development of modified and milk complexed-oilseed protein ingredients. In Annual Progress Report September 1, 1983 - August 31, 1984, Food Protein Research and Development Center, Texas Engineering Experiment station ,Texas A\&M University.

30. Ponnamplaan, R., Goulet, G., Amiot, J. and Brisson, C.J. (1987).Some functional and nutritional properties of oat flours as affected by proteolysis. J.Agric Food Chem 35, 279-285.

31. Mahmoud, M.. (1994). Physicochemical and functional properties of protein hydrolysates in nutritional products. Food Technol 48, 89-95.
32. Cha,,H. M. and Yoon, S. (1993). Modification of functional properties of soy protein isolate by proteolytic hydrolysis. Korean J. Food Sci. Technol. 16, 211-217 (51 FSTA)

33. Hermansson, A.M., Olsson, D. and Holmberg. B.(1974). Functional properties of proteins for foods: Modification of rapeseed protein concentrate. Lebens-Wissu u. Technol 7, 176-181.

34. Kang, Y.J(1984). Enzymatic modification of soy proteins: effects of functional properties upon proteolytic hydrolysis. Korean J. Food Sci \& Technol16, 211-217. (51: FSTA).
Recibido: Febrero 2001 Aceptado: Diciembre 2001 